\title{
Nest Site Selection of Loggerhead and Leatherback Sea Turtles at the Eastern Coast of Inhaca Island, Mozambique
}

\author{
Vera Cristina de Menezes Julien ${ }^{1}$, Almeida Tomás Guissamulo ${ }^{2}$, Armindo Filipe da Silva ${ }^{3}$ and Adriano Afonso \\ Macia Júnior ${ }^{1}$ \\ 1. Department of Biological Sciences, University Eduardo Mondlane, P. O. Box 257, Maputo, Mozambique \\ 2. Natural History Museum, University Eduardo Mondlane, P. O. Box 257, Maputo, Mozambique \\ 3. Department of Mapping Sciences, National Statistics Institute, Maputo P. O. Box 493, Maputo, Mozambique
}

\begin{abstract}
Nest site selection represents an important reproductive strategy for sea turtles as it can strongly affect the development and survival of the offsprings and the reproductive fitness of the adults. In this study we analyzed the nest site selection of loggerhead and leatherback turtles and the factors correlated with that selection at Inhaca Island. The spatial position of the nests was recorded during sea turtles nests monitoring and six nesting seasons were used. Satellite images of Inhaca were used to characterize some of the beach features that might be correlated with nest site selection. Nest distribution analysis revealed that loggerhead turtles tend to spread their nests along the entire beach, but a higher aggregation of nests was evident at the northern most section of the eastern coast. Leatherback turtles tend to nest in a restricted area, with approximately $40 \%$ nests at the central sections of the coast. Beach height was the physical variable significantly correlated to loggerhead's nest density $(\mathrm{r}=0.309, \mathrm{~N}=125, P<0.01)$ while fin grain particles (specifically $0.125 \mathrm{~mm}$ grain size particles) $(\mathrm{r}=0.399, \mathrm{~N}=125, P<0.01)$ and organic content $(\mathrm{r}=0.218, \mathrm{~N}=125, P<0.05)$ were the variables significantly correlated to leatherback's nest density. No other factors investigated affected nest site selection of either species.
\end{abstract}

Key words: Spatial nest distribution, nesting pattern of distribution, nest site selection, sea turtles, factors affecting nest site selection, Inhaca Island.

\section{Introduction}

Nest site selection is defined as the non-random placement of eggs within a particular location of a nesting beach [1-3]. That selection involves three phases: (1) beach selection, (2) female emergence and (3) nest placement. The decision to nest and emerge on a certain beach is probably determined by offshore cues and beach characteristics [4]. Once a sea turtle emerges from the ocean to a nesting beach, she usually enters to a "large" and diverse environment on which she must choose where to dig the nest [5]. That selection represents an important aspect for any oviparous organism [5-8]. It involves a trade-off

Corresponding author: Vera Cristina de Menezes Julien, $\mathrm{MsC}$, assistant, research field: marine biology. between the cost of searching for a place to nest and the reproductive benefits of choosing a "successful" nest site [2, 4].

As sea turtles lack parental care [1,2,9], a mother's behavior and preferences can strongly affect the development and survival of their offspring and therefore have important consequences for the reproductive fitness of the adult [6]. Serious outcomes can come from that choice [10]. Nesting near the sea may result in nest inundation by waves or eggs loss through beach erosion $[4,11]$. On the other hand, nest placement too far inland may increase the chances of nest desiccation, affect the ability of hatchlings in finding the sea and increase the risk of predation of the adult females, their eggs and hatchlings [4]. Moreover, nesting near the supralittoral vegetation 
may also reduce the reproductive output as plant roots may penetrate the nests and destroy the eggs $[4,11]$. Therefore, female turtles are forced to maximize their efforts on selecting a favorable nesting site for the development and hatching of her offspring's [2].

Several physical factors have been associated with nest site selection by sea turtles, namely: the presence of rocks [12], beach width, slope and vegetation cover $[8,13,14]$, salinity, particle size of the sand, $\mathrm{pH}$, organic content, conductivity, water content and salinity $[8,14]$. Most of the nest site selection studies consider each environmental cue independently, but there is the possibility of sea turtles using not one, but multiple factors to determine nest site selection, either by combining environmental information or even by using thresholds that must be reached for each factor [4].

In this study we analyze sea turtles nest site selection at Inhaca Island, Southern Mozambique, which has the largest database on sea turtles nidification in Mozambique ( 27 years). We aimed to use the monitoring results to understand the nesting preferences by of sea turtles at Inhaca. This can improve the effectiveness of conservation programs and/or be useful to promote sea turtle based tourism in the Island. The specific objectives set for this study were: (1) map the nest site locations for loggerhead and leatherback turtles at the eastern coast of Inhaca Island using the nesting seasons between 1987/88 and 2013/14; (2) identify sea turtles most selected nesting areas along the eastern coast of Inhaca Island and (3) identify the beach features that determine the nest site selection for loggerhead and leatherback turtles at the eastern coast of Inhaca Island.

\section{Methods}

\subsection{Study Area}

The study area comprised the entire eastern coast of Inhaca Island, which includes the administrative post of Inguane, KaNyaka Municipal district, Maputo City, Mozambique.
Inhaca Island is a distorted H-shaped island, located $32 \mathrm{~km}$ east of Maputo. It extends $12.5 \mathrm{~km}$ from its northern point-Ponta Mazondue, to the southern-eastern point-Ponta Torres, and it's about 7 $\mathrm{km}$ across the widest part in the central area, occupying a surface of about $40 \mathrm{~km}^{2}[15,16]$. The eastern coast of the Island faces the Indian Ocean while the western coast faces Maputo Bay [15, 17]. The Island is located between Northing 7,128,699.79 $\mathrm{m}-714,699.79 \mathrm{~m}$ and Easting 36,489,048.02 m-499,964.43 m [15, 17] (Fig. 1).

\subsection{Data Collection Procedure}

This study was carried out using the spatial coordinates of sea turtles nests collected during the sea turtles monitoring at Inhaca Island. During monitoring, the nest locations were recorded on topographic charts (1: $50,000 \mathrm{~m}$ ) by handwritten signals by the MBRS wildlife rangers (1987-2012). For the 2013/14 nesting

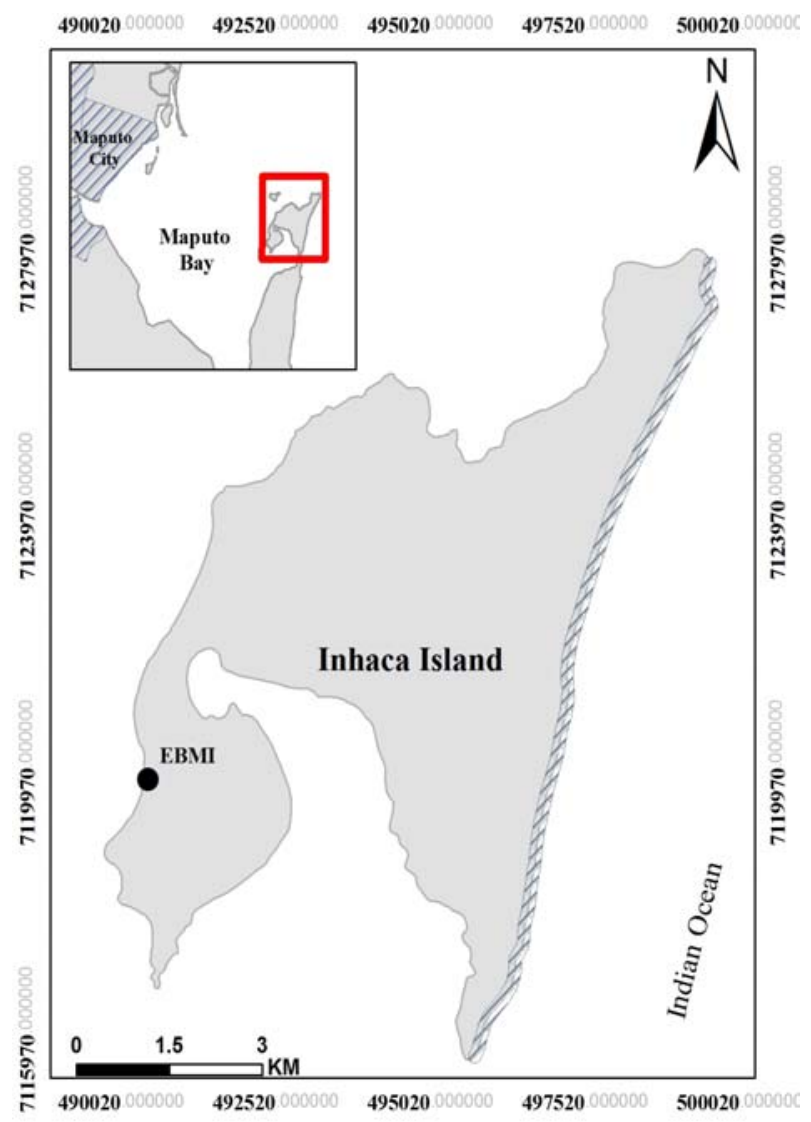

Fig. 1 Location of the study area, eastern coast of Inhaca Island, Maputo Province, Mozambique. 
season, nest locations were recorded in the field using a hand held Global Positioning System (Garmin-eTrex HCx) (GPS). After a preliminary analysis of the data collected only six nesting seasons were used to map the nest locations by sea turtles on the Island (1987/1988, 1989/1990, 1990/1991, 2001/2002, 2002/2003 and 2013/14). Data from the other nesting seasons were missing.

\subsection{Mapping the Nest Sites}

Topographic charts with handwritten locations of nests were converted into a digital format (raster model), which was then imported to the GIS-ArcMap 10 software. The raster model data was geometrical corrected to Universal Transversal Mercator-UTM system, spheroid of WGS 1984, Zone $36 \mathrm{~S}$ and converted into a shapefile format. The data collected at the field was also converted to an UTM system.

Nest locations of the 5 nesting seasons were merged into a single file. Nesting sites feature were categorized per species and displayed on a map of the Inhaca Island.

\subsection{Beach Sections}

Using the GIS-ArcMap 10 software, the length of the eastern coast of the Island was divided into 6 sections of approximately $2 \mathrm{~km}$ each. Within each section, 20 transects were displayed and separated by intervals of $100 \mathrm{~m}$ each [18]. Transects were perpendicular to the sea.

Satellite images of Inhaca Island from 2014 were downloaded from Google ${ }^{\mathrm{TM}}$. Earth, and used for a characterization of some beach features in order to use them against the selection of nesting sites by sea turtles. Seven beach features were measured along each transect and used to characterize the sections:

(1) Beach width, the distance from the spring high tide mark to the beginning of the pioneers' vegetation [19], was measured at the field, using a $100 \mathrm{~m}$ graduated tape. (2) Beach height was extracted from digital elevation model. The upper limit of the beach height consisted of the maximum distance inland traveled by a pregnant turtle during the nesting over the nesting years $(100 \mathrm{~m})$. The lower limit was the average sea level. The area of (3) pioneer's vegetation, (4) dune scrub and (5) bare dunes were obtained from the Google Earth's satellite image. On ArcMap 10, the area of each feature was measured.

20 sediment samples were collected per section (1 sample per transect), in the beginning of the pioneers vegetation, using a core sampler to a depth of $10 \mathrm{~cm}$. These were analyzed in terms of granulometric and organic content. Samples collected were stored before analysis (which took place at the Ecology Laboratory of the Biological Sciences Department-Eduardo Mondlane's University). Each soil sample was dried in an oven at a constant temperature of $60^{\circ} \mathrm{C}$ for $48 \mathrm{~h}$. Then, soil texture (variable 6) was measured trough particle size analysis using a set of sieves $(2,000 \mathrm{~mm}$; $1,000 \mathrm{~mm} ; 0.5 \mathrm{~mm} ; 0.25 \mathrm{~mm} ; 0.125 \mathrm{~mm} ; 0.063 \mathrm{~mm}$ and bottom) [8].

Organic content of the soil (variable 7) was determined by combustion of soil samples, of $1 \mathrm{~g}$ each, in a muffle furnace at a temperature of $550{ }^{\circ} \mathrm{C}$ during 2 h. Organic content (loss-on-ignition) was determined using the following equation [20]:

$$
\text { Loss on ignition }(\%)=\frac{\text { weight loss }(g) \times 100}{\text { oven dried weight }(g)}
$$

\section{Data Analysis}

All statistical analysis was performed using SPSS version 20.

\subsection{Identification of the Most Selected Nest Sites}

Density of nests was calculated for each section using the adaptive kernel density method in ArcMap 10 [21]. The area of each section corresponded to: length of the beach section $(2,000 \mathrm{~m}) \times$ beach height (distance between maximum distance inland traveled by a pregnant turtle during the nesting over the nesting years and average sea level-approximately $100 \mathrm{~m}$ ). One-way ANOVA tests were performed to compare 
the nest density of loggerhead and leatherback turtles between the 6 sections of the beach [22]. When ANOVA results were significant, pos-hoc analysis (Fisher's least significant difference test) was performed to identify the most selected sections [23].

\subsection{Determination of the Beach Features that Affect Nest Selection}

To identify the beach features that affect nest site selection a Correlation Test (Pearson Correlation) was performed between the set of variables and nest density. When a significant correlation was found those variables were submitted to a multiple logistic regression [22]. Multiple logistic regressions enabled the estimation of the relationship between the nest density and the multiple independent variables. This analysis also enabled to understand which, among the independent variables had significant influence on sea turtles nest site selection. This was done for each species.

\section{Results}

\subsection{Loggerhead's Nests Distribution}

Fig. 2 (a) illustrates the loggerhead's nest distribution at Inhaca Island over 6 nesting seasons and the mean density of loggerheads nests in the 6 sections of the beach. Nest density was significantly different along the 6 sections of the eastern coast of the Island $(F(5,119)=9.888, P<0.05)$. Loggerhead's nest density was higher in the northern most section of the eastern coast (section A) and statistically different from the other 5 sections. Moving southward from Ponta Mazóndue to Ponta Torres, the nest numbers tended to decrease and nest distribution tended to become scattered. Section D and E presented the lowest nest density among the other sections with no significantly differences between them.

\subsection{Leatherback's Nests Distribution}

Fig. 2 (b) shows the leatherback's nests distribution at Inhaca Island.
Leatherback's nest density was significantly different across the sections $(\mathrm{F}(5,119)=16.637, P<0.05)$.

The density of nests at the central section of the eastern coast were higher (section C) and statistically different from the other 5 sections. Sections D, E and $F$ had the lowest nest density with no statistical differences between them.

\subsection{Beach Sections Characterization}

Beach sections were described according to the beach features collected at each transect. Table 1 shows the mean values of the beach features for each section.

Significant statistical differences were observed in the mean values of beach width between the beach sections $(F(5,119)=3.063, P<0.05)$. Section B presented the highest mean value of beach width compared to the other sections. However, no significant differences were observed with and between the sections A, C and D. Section E and F had the lowest mean values of beach width, with no significant differences between them.

Beach height was statistically different across beach sections $(F(5,119)=60.741, P<0.05)$. Section A and $B$ had the highest mean values of beach height. Beach height was lower at section $\mathrm{F}$ and significantly different from all the other sections.

No significant differences were observed on the percentage of very coarse sand $(2 \mathrm{~mm})$ between the sections $(\mathrm{F}(5,119)=1.014, P>0.05)$. Coarse sand $(1$ $\mathrm{mm}$ ) was statistically different between the sections (F $(5,119)=8.271, P<0.05)$. Section $\mathrm{F}$ had the highest mean percentage of coarse sand however it was not statistically different from section B. The percentage of medium sand $(0.5 \mathrm{~mm})$ differed across beach sections $(F(5,119)=28.370, P<0.05)$ and was higher at section $\mathrm{F}$. The percentage of fine sand $(0.25$ $\mathrm{mm})$ was statistically different between the beach sections $(\mathrm{F}(5,119)=19.304, P<0.05)$. The sections $\mathrm{C}, \mathrm{D}$ and $\mathrm{E}$ presented the highest percentage of fine sand with no statistical difference between them. The 

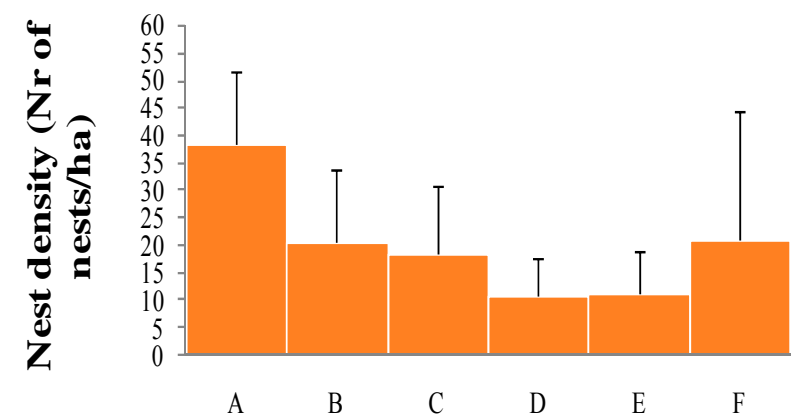

$\stackrel{N}{\Lambda}$

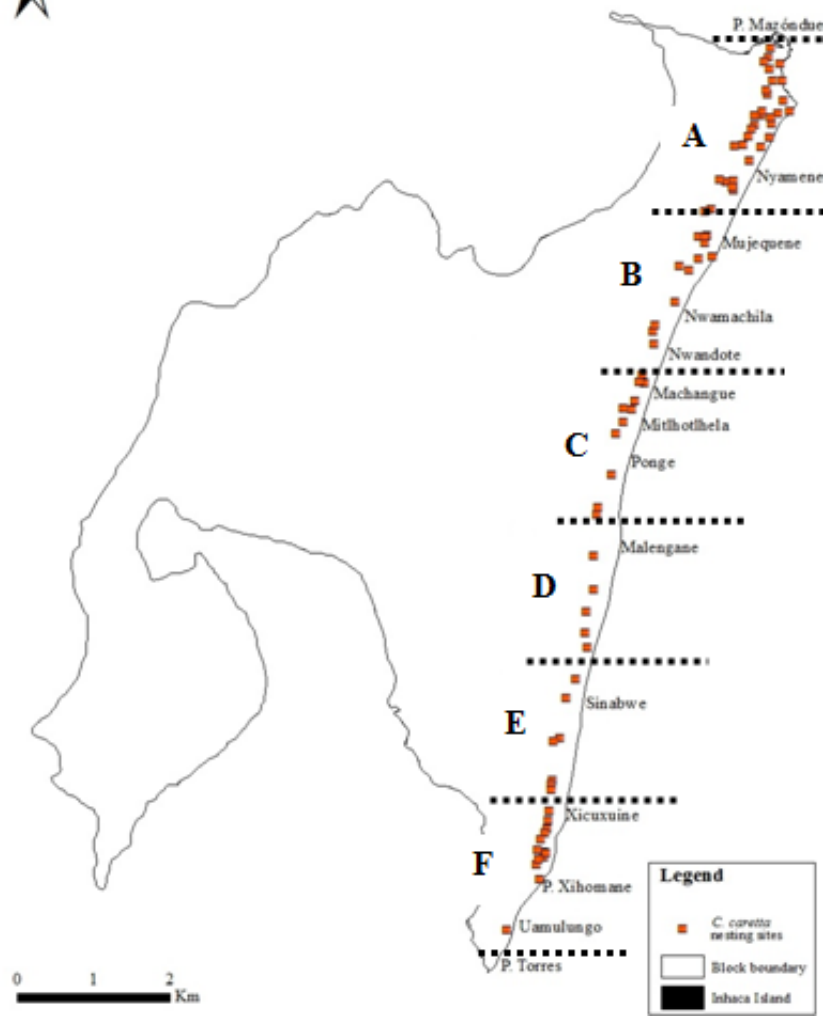

(a)

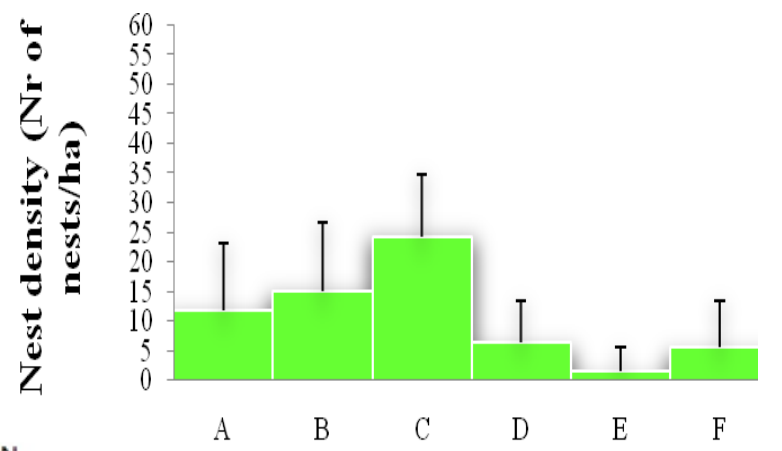

$\stackrel{N}{\Lambda}$

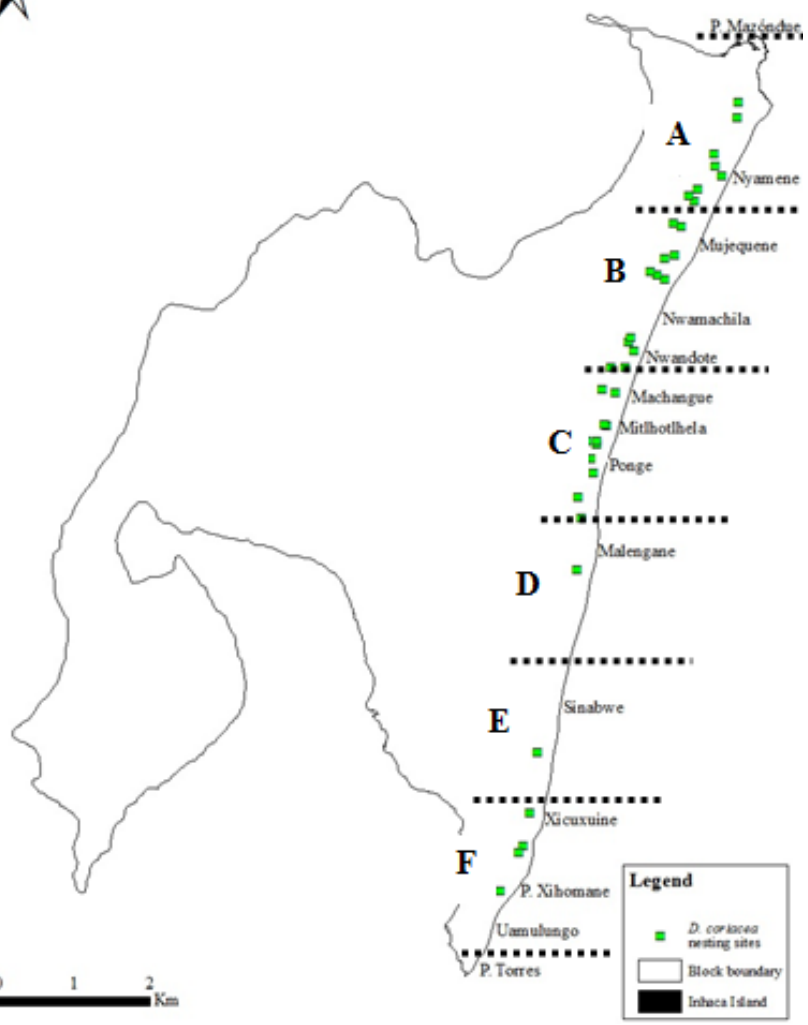

(b)

Fig. 2 Spatial distribution of loggerhead (C. caretta) (a) and leatherback nesting sites (D. coriacea) (b) at the eastern coast of Inhaca Island.

percentage of very fine sand $(0.125 \mathrm{~mm})$ was also different across beach sections $(\mathrm{F}(5,119)=50.826, P$ $<0.05)$. Section $\mathrm{C}$ presented the highest percentage of very fine sand and was statistically different from the other sections.

No significant differences were observed on the percentage of organic content across the studied sections $(\mathrm{F}(5,119)=0.961, P>0.05)$.

The percentage cover of bare dune, pioneer's vegetation and dune scrub did not differ across all sections $\left(\mathrm{F}(5,119) \mathrm{F}_{1}=0.485, \mathrm{~F}_{2}=0.409, \mathrm{~F}_{3}=1.237\right.$, $P>0.05$ respectively).

\subsection{Factors Affecting Nest Site Selection}

\subsubsection{Loggerhead Sea Turtles}

Only one significant correlation was found between nest density of loggerhead turtles and beach parameters. Loggerhead's nest density was significant and positive correlated with beach height $(\mathrm{r}=0.309, \mathrm{~N}$ $=125, P<0.01)$. 
Table 1 Mean values of the beach features across the 6 sections of the eastern coast of Inhaca.

\begin{tabular}{|c|c|c|c|c|c|c|c|c|c|c|c|}
\hline \multirow{2}{*}{$\begin{array}{l}\text { Beach } \\
\text { sections }\end{array}$} & \multicolumn{11}{|c|}{ Beach features } \\
\hline & $\begin{array}{l}\text { BW } \\
(\mathrm{m})\end{array}$ & $\begin{array}{l}\text { ALT } \\
(\mathrm{m})\end{array}$ & $\begin{array}{l}2 \mathrm{~mm} \\
\mathrm{GSP}(\%)\end{array}$ & $\begin{array}{l}1 \mathrm{~mm} \\
\mathrm{GSP}(\%)\end{array}$ & $\begin{array}{l}0.5 \mathrm{~mm} \\
\mathrm{GSP}(\%)\end{array}$ & $\begin{array}{l}0.25 \mathrm{~mm} \\
\mathrm{GSP}(\%)\end{array}$ & $\begin{array}{l}0.125 \mathrm{~mm} \\
\text { GSP (\%) }\end{array}$ & $\begin{array}{l}\mathrm{OC} \\
(\%)\end{array}$ & $\begin{array}{l}\text { BDA } \\
\text { (\% cover) }\end{array}$ & $\begin{array}{l}\text { PVA } \\
\text { (\% cover) }\end{array}$ & $\begin{array}{l}\text { DSA } \\
\text { (\% cover) }\end{array}$ \\
\hline A & 16.04 & 50.30 & 0.08 & 0.94 & 36.70 & 56.98 & 5.20 & 1.20 & 24.27 & 10.35 & 65.09 \\
\hline B & 18.39 & 47.65 & 0.13 & 1.74 & 37.76 & 53.63 & 6.74 & 0.81 & 49.24 & 24.91 & 25.85 \\
\hline $\mathrm{C}$ & 16.55 & 24.20 & 0.00 & 0.09 & 9.57 & 71.33 & 19.01 & 1.43 & 48.38 & 45.41 & 6.20 \\
\hline $\mathrm{D}$ & 15.55 & 31.60 & 0.03 & 0.31 & 21.58 & 69.43 & 8.65 & 0.80 & 32.89 & 30.60 & 36.51 \\
\hline $\mathrm{E}$ & 12.66 & 35.50 & 0.07 & 0.67 & 24.96 & 66.32 & 7.98 & 0.68 & 49.77 & 19.51 & 30.72 \\
\hline $\mathrm{F}$ & 13.13 & 15.84 & 0.21 & 2.58 & 48.42 & 45.79 & 3.01 & 0.96 & 17.77 & 63.36 & 18.87 \\
\hline \multicolumn{5}{|c|}{ Legend: } & \multicolumn{7}{|c|}{$0.25 \mathrm{~mm}$ GSP $-0.25 \mathrm{~mm}$ grain sized particles } \\
\hline \multicolumn{5}{|c|}{ BW-Beach width } & \multicolumn{7}{|c|}{$\mathbf{0 . 1 2 5} \mathbf{~ m m ~ G S P}-0.125 \mathrm{~mm}$ grain sized particles } \\
\hline \multicolumn{5}{|c|}{ ALT_Beach height } & \multicolumn{7}{|c|}{ OC-Organic content } \\
\hline \multicolumn{5}{|c|}{$2 \mathrm{~mm}$ GSP $-2 \mathrm{~mm}$ grain sized particles } & \multicolumn{7}{|c|}{ BDA-Bare dune area } \\
\hline \multicolumn{5}{|c|}{$1 \mathrm{~mm}$ GSP $-1 \mathrm{~mm}$ grain sized particles } & \multicolumn{7}{|c|}{ PVA_Pioneer's vegetation area } \\
\hline \multicolumn{5}{|c|}{$0.5 \mathrm{~mm}$ GSP $-0.5 \mathrm{~mm}$ grain sized particles } & \multicolumn{7}{|c|}{ DSA-Dune scrub area } \\
\hline
\end{tabular}

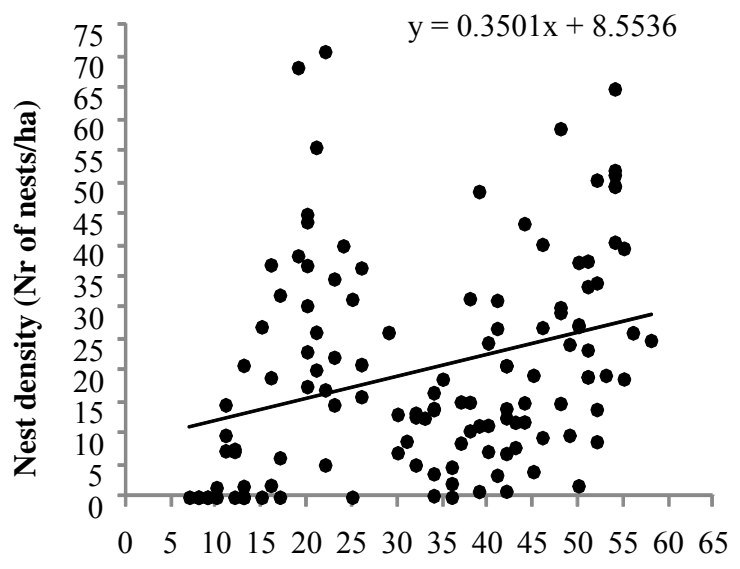

Beach Height (m)

Fig. 3 Relationship between loggerheads nest density and beach height $\left(r^{2}=0.095\right)$.

According to the regression model expressed on Fig. 3 , the increase of 1 unit of beach height means an increase of 0.35 units in the loggerheads nest density. This model explains $9.5 \%$ of the beach height variation (Fig. 3).

\subsubsection{Leatherback Sea Turtles}

Three significant correlations were observed between beach parameters and leatherbacks nest density. Leatherbacks nest density was significantly positive correlated with the $0.125 \mathrm{~mm}$ grain sized particles $(\mathrm{r}=0.399, \mathrm{~N}=125, P<0.01)$ and organic content $(\mathrm{r}=0.218, \mathrm{~N}=125, P<0.05)$, and significantly negative correlated with the $0.5 \mathrm{~mm}$ grain sized particles $(\mathrm{r}=-0.262, \mathrm{~N}=125, P<0.01)$.

The final model of the logistic regression analysis only considered two factors: the $0.125 \mathrm{~mm}$ grain sized particles and the organic content percentage. $0.5 \mathrm{~mm}$ grain sized particles was removed from the analysis as no statistically significance were observed in the determination of leatherbacks nest density. This model explains $19.4 \%$ of the nest density variation.

As shown on the regression model on figure 4.7 (a and b), when this two factors act independently, an increasing of one unit of $0.125 \mathrm{~mm}$ grain sized particles results on an increase of 1,213 units of nest density. And an increasing of one unit of the organic content percentage results on an increase of 1.65 units of leatherback nest density. $15.9 \%$ of the nest density is explained by the $0.125 \mathrm{~mm}$ grain sized particles and $4.8 \%$ is explained by the organic content of the soil.

\section{Discussion}

\subsection{Spatial Nest Distribution}

Inhaca Island has 4 distinct shores, of which the eastern is the only shore that have records of sea turtles nidification. The following characteristics are the most important on the selection of the eastern coast for nidification: (1) it's easy access from/to the ocean and obstacle free. The southern and northern coasts are characterized by the presence of "air-roots", 


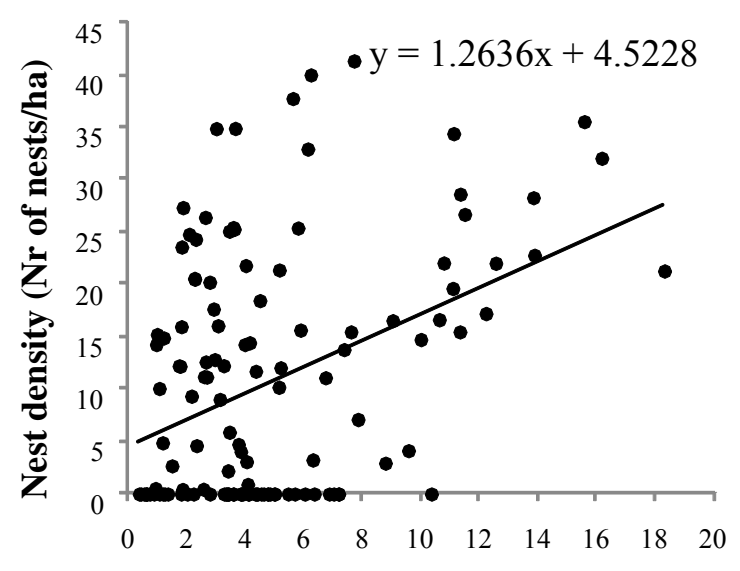

\% of finer sand $(0.125 \mathrm{~mm})$

(a)

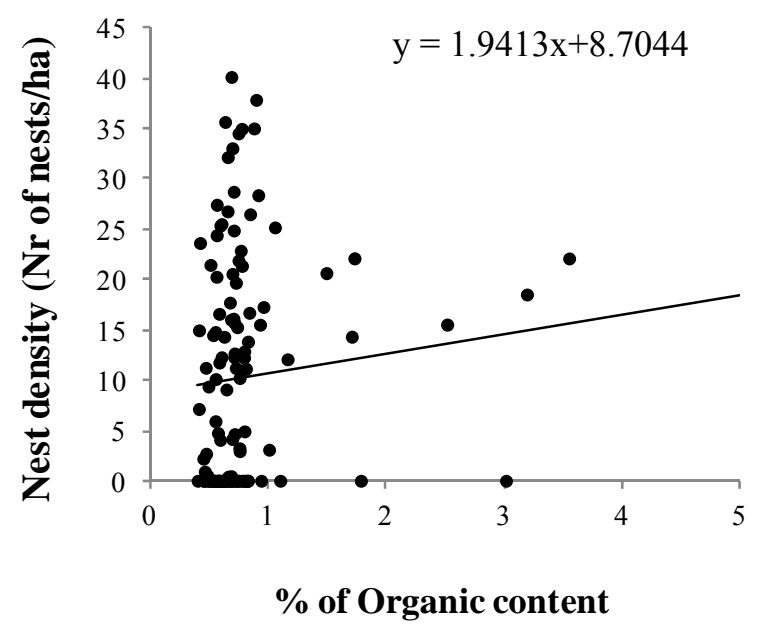

(b)

Fig. 4 Relationship between leatherbacks nest density and percentage of finer sand (a) $\left(r^{2}=0.159\right)$ and organic content (b) $\left(r^{2}=0.048\right)$.

called pneumatophores. These roots usually cover part of the forest floor and may hinder sea turtles access or nest excavation; (2) the presence of elevated platforms to reduce the risk of nests being destroyed by waves or high tides $[3,15,24]$. The other three shores are mainly characterized by inferior topographic bottom slopes; and (3) the presence of large grain particles (0.5-1 $\mathrm{mm})$ to allow gas exchange between eggs and sand, providing an optimum environment for embryonic development [25]. The gradient and steepness of the shore reflects the energy conditions of the beach (which are high at the east coast).
Along the eastern coast, the loggerheads tendency of spreading their nests throughout the coast contradicted the findings made by other authors [7, 10], which stated that loggerhead turtles tend to lay their eggs in a non-random pattern. Leatherbacks tendency to nest in specific areas of the beach also contradicted other authors findings [1, 2], that leatherbacks usually spread their nests evenly along the beach. The differences observed between these studies $[2,10,25]$ with the present, could be due to the different sampling methods applied. Although the present study had grouped the several years data and treated as a single temporal unit as the other studies, it did not use a consecutive chronological sequence of the spatial data, like the other authors, because spatial data from many nesting seasons were missing. One of the main disadvantages of grouping several years data as a single temporal unit relies in the fact that it does not consider spatial changes over the years.

Individual loggerhead turtles have a strong sense of orientation and memory as they use chemical cues to locate their nesting sites. They usually present the same pattern between or across nesting seasons [2]. On the other hand, individual leatherback turtles nest in a random pattern in order to maximize nest survival in unpredictable environments [25].

\subsection{Factors Affecting Nest Site Selection}

Loggerheads tendency to nest most towards the northern end of the beach against leatherbacks tendency to nest most towards the middle of the beach could mean that these two species have different nesting preferences.

Beach height was significantly correlated with loggerhead's nest density at the eastern coast of Inhaca. Similar findings were obtained by other authors $[4,27,28]$. No other variable had importance on the nest selection process. By being much lighter and smaller of the two species, loggerhead turtles eventually have more choices of nesting sites and are able to move easily or climb high altitudes in order to 
find higher nesting sites to reduce the risk of nests being inundated or destroyed by waves and increase the probability of embryonic development success [3]. However, this model only explained $9.5 \%$ of loggerheads nest density variation, which might mean that there are other important variables influencing loggerheads nest site selection.

Leatherback's nest density was significantly correlated to very fine sand $(0.125 \mathrm{~mm}$ grain sized particles) and organic content of the sediment. According to [25], higher percentages of fine sand and organic content can be linked to the exposure to ongoing water run-off that results in the deposition of finer material in certain portions of the beach. However, that is not the case of Inhaca, since there is no river near the Island. It is probable that the fine, less heavy particles, are dragged by the wind and deposited in this section of the beach, creating large amounts of fine material.

Fine particles can reduce the hatch success by restricting the gas exchange between the eggs and the sand [25]. However, leatherback turtles don't appear to choose their nest sites based on the chances of hatchling success. It appears that leatherbacks only choose their nest sites under the practicality to handle their heavy bodies [2]. Coarse-grained sections are difficult to excavate, therefore, leatherback turtles probably choose to nest on finer sands due to the practically to dig their nests [29]. Additionally, finer sand particles are correlated to softer/gentle slopes which are easier to crawl. However, this model only explains about $19 \%$ of leatherbacks density variation. Therefore, further research is required to have a broader understanding of the factors controlling the nest site selection by leatherback turtles.

\section{Conclusions}

Spatial distribution analysis revealed that loggerhead turtles tended to spread their nests along the coast, but with a preference for the northern most section, while leatherbacks tended to nest in the middle section of the beach. Of the seven beach features measured, beach height was the most important factor controlling the nest selection by loggerhead turtles while very fine sand particles and organic content of the soil were considered important factors on the nest selection by leatherback turtles.

\section{Aknowledgments}

We are extremely grateful to Ocean Revolution who provided financial support to implement this research. Furthermore, we would like to thank Timothy Dykman for his great support to this research. We thank Dr. Albano G., head of the Inhaca's Marine Biological and Research Station (MBRS), who gave us the opportunity to develop this research at Inhaca Island and provided all the necessary support. We also thank Adá A., Mucavele T. and all the wildlife rangers of the MBRS.

We also thank S. Major for providing guidance and help with statistical analysis.

\section{References}

[1] Kamel, S. J., and Mrosovsky, N. 2005. "Repeatability of Nesting Preferences in the Hawksbill Sea Turtle, Eretmochelys imbricata, and Their Fitness Consequences." Animal Behavior 70: 819-28.

[2] Botha, M. 2010. "Nest Site Fidelity and Nest Site Selection of Loggerhead, Caretta caretta, and Leatherback, Dermochelys coriacea, Turtles in Kwazulu-Natal, South Africa." MSc Thesis, Nelson Mandela Metropolitan University.

[3] Trindade, J. C. C. N. 2012. "Factores que influenciaram a escolha da praia de nidificação por tartarugas verdes (Chelonia mydas) em Vamizi, Moçambique, entre 2003 e 2012." MSc Thesis, Universidade de Lisboa.

[4] Wood, D. W., and Bjorndal, K. A. 2000. "Relation of Temperature, Moisture, Salinity, and Slope to Nest Site Selection in Loggerhead Sea Turtles." Copeia 1: 119-28.

[5] Bjorndal, K. A., and Bolten, A. B. 1992. "Spatial Distribution of Green Turtle (Chelonia mydas) Nests at Tortuguero, Costa Rica." Copeia 1: 45-53.

[6] Hays, G. C., and Speakman, J. R. 1993. "Nest Placement by Loggerhead Turtles, Caretta caretta." Animal Behaviour 45: 47-53.

[7] Hays, G. C., Mackay, A., Adams, C. R., Mortimer, J. A., Speakman, J. R., and Boerema, M. 1995. "Nest Site Selection by Sea Turtles." Journal of Marine Biological Association of the United Kingdom 75: 667-74. 
[8] Mazaris, A. D., Matsinos, Y. G., and Margaritoulis, D. 2006. "Nest Site Selection of Loggerhead Sea Turtles: the Case of the Island of Zakynthos, W Greece." Journal of Experimental Marine Biology and Ecology 336: 157-62.

[9] Broderick, A. C., Glen, F., Godley, B. J., and Hays, G. C. 2003. "Variation in Reproductive Output of Marine Turtles." Journal of Experimental Marine Biology and Ecology 288: 95-109.

[10] Miller, J. D., Limpus, C. J, and Godfrey, M. H. 2003. Nest Site Selection, Oviposition, Eggs, Development, Hatching, and Emergence of Loggerhead Turtles. In The Biology of Sea Turtles, edited by Lutz, P. L., Musick, J. A., Wyneken, J., Washington, DC: Smithsonian Books.

[11] Kamel, S. J., and Mrosovsky, N. 2004. "Nest Site Selection Inleatherbacks, Dermochelys Coriacea: Individual Patterns and Their Consequences." Animal Behaviour 68: 357-66.

[12] Brazier, W. 2012. Environmental Cues and Sensory Preferences Directing the Nesting Process in Loggerhead Turtles, Caretta caretta, Nesting in Maputaland, South Africa. MSc Thesis, Nelson Mandela Metropolitan University.

[13] Weishampel, J. F., Bagley, D. A., Ehrhart, L. M., and Rodenbeck, B. L. 2003. "Spatiotemporal Patterns of Annual Sea Turtle Nesting Behaviors along an East Central Florida Beach." Biological Conservation 110: 295-303.

[14] Kaska, Y., Başkale, E., Urhan, R., Katılmış, Y., Gidiş, M., Sarı, F., Sözbilen, D., Canbolat, A. F., Yilmaz, F., Barlas, M., Özdemir, N., and Özkul, M. 2010. "Natural and Anthropogenic Factors Affecting the Nest-site Selection of Loggerhead Turtles, Caretta caretta, on Dalaman-Sangerme Beach in South-west Turkey." Zoology in the Middle East 50: 47-58.

[15] Kalk, M. 1995. A Natural History of Inhaca Island. Witwatersrand University Press.

[16] Bandeira, S., Hernroth, L., and da Silva, V. 2014. Inhaca Island-The Cradle of Marine Research in Maputo Bay and Mozambique. In: The Maputo Bay Ecosystem, edited by Bandeira, S. and Paula, J..

[17] de Boer, F. 2000. "Biomass Dynamics of Seagrasses and the Role of Mangrove and Seagrasses Vegetation as Different Nutrient Sources for an Intertidal Ecosystem in Mozambique." Aquatic Botany 66: 225-39.

[18] Magane, S. U. 2006. "Nesting Beach Preferences of Loggerhead (Caretta caretta) and Leatherback
(Dermochelys coriacea) Sea Turtles at Maputo Special Reserve (Mozambique), and Their Conservation and Management Implications." MSc Thesis. University of Leeds.

[19] Varela-Acevedo, E., Eckert, K. L., Eckert, S. A., Cambers, G., and Horrocks, J. A. 2009. Sea Turtle Nesting Beach Characterization Manual. In: Examining the Effects of Changing Coastline Processes on Hawksbill Sea Turtle (Eretmochelys imbricata) Nesting Habitat. Beaufort: Duke University.

[20] Allen, S. E. 1989. Chemical Analysis of Ecological Materials. Oxford: Blackwell Scientific Publications.

[21] Macandza, V. A., Owen-Smith, N., and Cain, J. W. 2012. "Dynamic Spatial Partitioning and Coexistence among Tall Grass Grazers in an African Savanna." OIKOS 121: 891-8.

[22] Reis, E., Melo, P., Andrade, R., and Calapez, T. 2006. Estatística Aplicada. Editora Sílabo.

[23] Pestana, M. H., and Gageiro, J. 2008. Análise de Dados para Ciências Sociais,. Editora Sílabo.

[24] Tärnlund, S. 1999. Sea Turtles on Inhaca Island, Mozambique: A Field Survey and Compilation of Historical and Recent Unpublished Nesting Data. Swedmar Working Paper, Göteborg University.

[25] Maison, K. A., King, R., Lloyd, C., and Eckert, S. 2010. "Leatherback Nest Distribution and Beach Erosion Pattern at Levera Beach, Grenada, West Indies." Marine Turtle Newsletter 127: 9-12.

[26] Lamont, M. M., and Houser, C. 2014. "Spatial Distribution of Loggerhead Turtle (Caretta caretta) Emergences along a Highly Dynamic Beach in the Northern Gulf of Mexico." Journal of Experimental Marina Biology and Ecology 453: 98-107.

[27] Provancha, J. A., and Ehrhart, L. M. 1997. Sea Turtle Nesting Trends at Kennedy Space Center and Cape Cnaveral Air Force Station, Florida, and Relationships with Factors Influencing Nest Site Selection. Florida: NOAA Technical Report.

[28] Kikukawa, A., Kamezaki, N., and Ota, H. 1990. "Factors Affecting Nesting Beach Selection by Loggerhead Turtles (Caretta caretta): a Multiple Regression Approach.” Journal of Zoology 249 (4): 447-54.

[29] Mortimer, J. A. 1990. "The Influence of Beach Sand Characteristics on the Nesting Behaviour and Clutch Survival of Green Turtles (Chelonia mydas)." Copeia 1990: 447-51. 